\title{
Early Holocene sea-level changes in Øresund, southern Scandinavia
}

\author{
Ole Bennike, Martin Skov Andreasen, Jørn Bo Jensen, Matthias Moros and Nanna Noe-Nygaard
}

The Baltic Sea and Kattegat are connected via three straits: Storebælt, Lillebælt and Øresund (Fig. 1). Øresund is the shallowest with a threshold around $7 \mathrm{~m}$ deep and increasing water depths to the north (Fig. 2). In the early Holocene, global sea-level rise led to reflooding of Øresund. It started in northern Øresund which was transformed into a fjord. However, so far the timing of the transgression has not been well determined, but sediment cores collected north of the threshold, at water depths of 12 to $20 \mathrm{~m}$, and a new series of radiocarbon ages help to constrain this. As the relative sea level continued to rise, the threshold in Øresund was also flooded, and Øresund became a strait. In mid-Holocene time, the relative sea level rose until it was $4-5 \mathrm{~m}$ higher than at present, and low-lying areas around Øresund became small fjords. During the late Holocene, the relative sea level fell again. Part of the data set discussed here was presented by Andreasen (2005).

Active glacier ice disappeared from the region around 17 cal. ka BP (calibrated kilo-years before present; HoumarkNielsen \& Kjær 2003). During deglaciation, the ice margin receded southwards and huge amounts of meltwater flowed northwards and formed deep holes and channels.

Shortly after the deglaciation of the region, marine waters inundated Øresund and remains of Arctic species such as

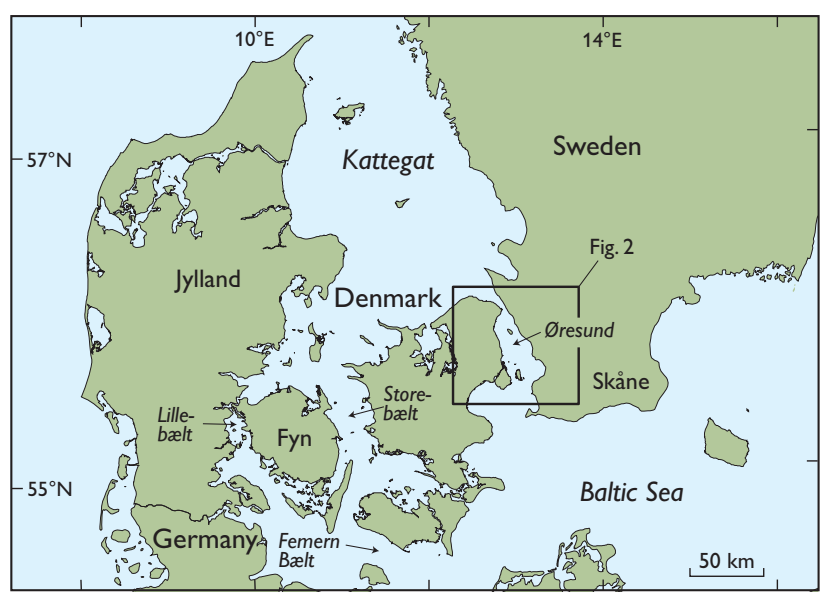

Fig. 1. Map of Denmark and the surrounding area showing the location of Øresund and other place names mentioned in the text. polar cod (Boreogadus saida) and ringed seal (Phoca hispida) have been found and dated to around 16 and 17.6 cal. ka BP (Lagerlund \& Houmark-Nielsen 1993). During this time, the relative sea level must have been high, reflecting the loading of the Fennoscandian Ice Sheet during the Last Glacial Maximum.

Somewhat later Øresund played an important role in draining the Baltic Ice Lake, and a major delta formed north of Øresund. Radiocarbon dating of marine mollusc shells from the delta has given ages between 16.3 and $11.8 \mathrm{cal}$. ka BP. Following isostatic rebound the relative sea level fell, and major parts of Øresund became dry land with forests, lakes and peat bogs. Submarine lake and peat deposits from the Younger Dryas and the early Holocene have been reported (Jessen 1923). Several now submarine former settlements have been reported from Øresund (Fischer 1993), which can be referred to the Mesolithic based on artefacts and radiocarbon dating.

\section{Methods}

Sediment coring was carried out with a $10 \mathrm{~cm}$ diameter vibrocorer from R/V Alexander von Humboldt and R/V

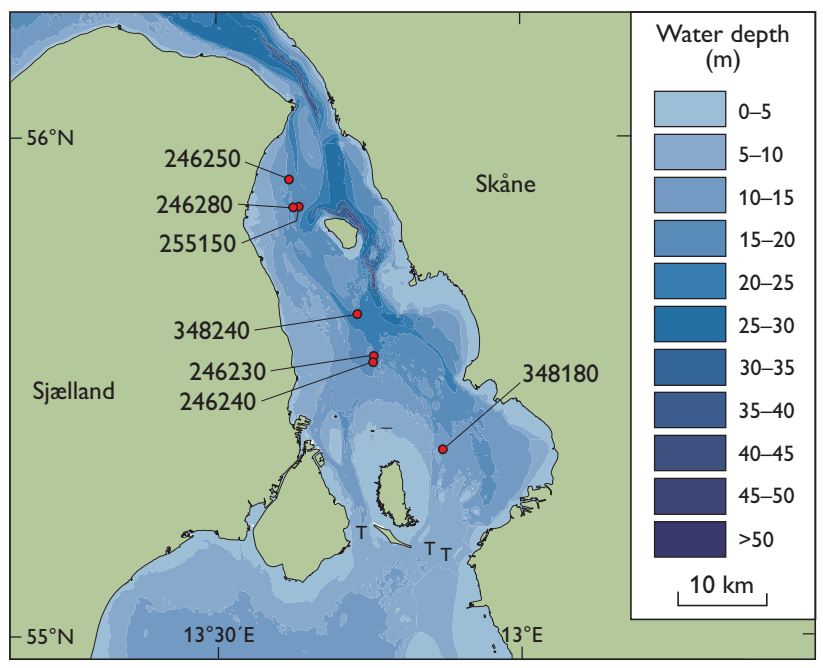

Fig. 2. Map of the Øresund region showing the bathymetry and the location of vibrocores. $\mathbf{T}$ : Threshold. 
Table 1. Selected radiocarbon ages from Øresund

\begin{tabular}{|c|c|c|c|c|c|c|c|c|}
\hline $\begin{array}{l}\text { Core/ } \\
\text { locality }\end{array}$ & $\begin{array}{c}\text { N. lat. } \\
\text { no. }\end{array}$ & W. long. & Lab. no. & Material & $\begin{array}{c}\text { Depth } \\
\text { bct* }(\mathrm{cm})\end{array}$ & $\begin{array}{l}\text { Depth } \\
\text { b.s.l. (m) }\end{array}$ & $\begin{array}{l}\text { Age }\left({ }^{14} C\right. \\
\text { years } B P)\end{array}$ & $\begin{array}{c}\text { Calibrated } \\
\text { age (years BP) }\end{array}$ \\
\hline 246230 & $55^{\circ} 46.801^{\prime}$ & $12^{\circ} 44.461^{\prime}$ & AAR-8284 & Mytilus edulis & $105-115$ & 21.2 & $8310 \pm 70$ & $8765-8981$ \\
\hline 246230 & $55^{\circ} 46.801^{\prime}$ & $12^{\circ} 44.461^{\prime}$ & AAR-8285 & Mytilus edulis & 542 & 25.5 & $9155 \pm 70$ & 9840-10101 \\
\hline 246230 & $55^{\circ} 46.801^{\prime}$ & $12^{\circ} 44.461^{\prime}$ & AAR-8286 & Phragmites australis & $560-570$ & 25.7 & $9445 \pm 70$ & $10569-10781$ \\
\hline 246240 & $55^{\circ} 46.440^{\prime}$ & $12^{\circ} 44.392^{\prime}$ & AAR-8287 & Macoma balthica & $120-130$ & 18.0 & $9200 \pm 70$ & 9907-10129 \\
\hline 246240 & $55^{\circ} 46.440^{\prime}$ & $12^{\circ} 44.392^{\prime}$ & AAR-8288 & Macoma balthica & $380-390$ & 20.6 & $9380 \pm 80$ & $10147-10333$ \\
\hline 246250 & $55^{\circ} 57.811^{\prime}$ & $12^{\circ} 36.327^{\prime}$ & AAR-8626 & Littorina littorea & $58-60$ & 16.4 & $8455 \pm 35$ & $9003-9109$ \\
\hline 246250 & $55^{\circ} 57.811^{\prime}$ & $12^{\circ} 36.327^{\prime}$ & AAR-8627 & Littorina littorea & $64-70$ & 16.5 & $8565 \pm 40$ & $9113-9301$ \\
\hline 246250 & $55^{\circ} 57.811^{\prime}$ & $12^{\circ} 36.327^{\prime}$ & AAR-8603 & Macoma balthica & $270-280$ & 18.7 & $9475 \pm 35$ & $10253-10372$ \\
\hline 246250 & $55^{\circ} 57.811^{\prime}$ & $12^{\circ} 36.327^{\prime}$ & AAR-8601 & Woody plant roots & $300-310$ & 18.9 & $8820 \pm 40$ & $9740-10115$ \\
\hline 246280 & $55^{\circ} 56.104^{\prime}$ & $12^{\circ} 36.696^{\prime}$ & AAR-8628 & Cerastoderma edulis & $203-207$ & 18.4 & $9270 \pm 45$ & 10 039-10189 \\
\hline 246280 & $55^{\circ} 56.104^{\prime}$ & $12^{\circ} 36.696^{\prime}$ & AAR-8630 & Wood & $215-223$ & 18.6 & $8940 \pm 40$ & $9941-10193$ \\
\hline 246280 & $55^{\circ} 56.104^{\prime}$ & $12^{\circ} 36.696^{\prime}$ & AAR-8604 & Phragmites australis & $220-230$ & 18.6 & $8975 \pm 50$ & $9951-10228$ \\
\hline 246280 & $55^{\circ} 56.104^{\prime}$ & $12^{\circ} 36.696^{\prime}$ & AAR-8631 & Corylus avellana & $352-356$ & 19.9 & $8740 \pm 35$ & $9606-9772^{\ddagger}$ \\
\hline 255150 & $55^{\circ} 56.144^{\prime}$ & $12^{\circ} 37.247^{\prime}$ & AAR-8632 & Scirpus spp. & $190-200$ & 20.3 & $8765 \pm 40$ & $9686-9887$ \\
\hline 348180 & $55^{\circ} 40.883^{\prime}$ & $12^{\circ} 51.410^{\prime}$ & Poz-42496 & Cladium mariscus & $365-370$ & 15.7 & $8660 \pm 50$ & $9546-9662$ \\
\hline 348240 & $55^{\circ} 49.398^{\prime}$ & $12^{\circ} 42.976^{\prime}$ & Poz-42497 & Phragmites australis & 400 & 26.0 & $9240 \pm 50$ & $10298-10498$ \\
\hline \multicolumn{3}{|l|}{ Pilhaken } & AAR-1225 & Corylus avellana & & 7.8 & $8120 \pm 90$ & $8980-9259^{\$}$ \\
\hline \multicolumn{3}{|l|}{ Pilhaken } & T-10667 & Quercus sp. & & 7.8 & $7945 \pm 75$ & $8649-8977^{\$}$ \\
\hline \multicolumn{3}{|c|}{ Svalerumpen } & K-6036 & Tree root & & 5.9 & $7680 \pm 115$ & $8386-8586^{\$}$ \\
\hline \multicolumn{3}{|c|}{ Svalerumpen } & T-10665 & Pinus sylvestris & & 6.5 & $8225 \pm 95$ & $9031-9300^{\$}$ \\
\hline
\end{tabular}

* Below core top. $†$ Calibration is according to the INTCAL09 data (terrestrial samples) and the Marine09 data (marine samples). $\ddagger$ Too young compared with the other dates from the core. $\$$ Fisher (1993).

Professor Penck. Coring positions were selected from highresolution shallow seismic profiles. The seismic equipment comprised a boomer, an X-star and a sediment echosounder. Differential GPS was used for navigation. The cores were split and described in the laboratory, and selected cores were subsampled for palaeoecological analyses. The samples were wet sieved on $0.4,0.2$ and $0.1 \mathrm{~mm}$ sieves, and the residue left on the sieves was analysed with a dissecting microscope. Macrofossils were identified using a reference collection. Remains of terrestrial plants and marine molluscs were used for accelerator mass spectrometry (AMS) radiocarbon age determination (Table 1).

\section{Results}

Most of the cores consisted of Holocene marine clayey and silty mud, sometimes with marine sand in the upper part. One core (348180) contained rootlet-peat overlain by sediment with numerous fruits of Cladium mariscus and shells of land gastropods. Core 348240 contained sediment with in situ rootlets tentatively identified as Phragmites australis.

Figure 3 shows an example of a macrofossil diagram. A total of 74 taxa were noted, but only 17 of them are shown in the simplified diagram. The sequence coarsens upwards; this is interpreted as an increased energy level as the sea level rose and the basin was transformed to a fjord. Common remains of tree birch (Betula sect. Albae) and pine (Pinus sylvetris, not shown) as well as rare remains of aspen (Populus tremula) indicate that the shore was not far away.

The lower part of the sequence is dominated by lacustrine taxa, such as the leach Erpobdella sp. and the bryozoan Cristatella mucedo. Shells and head shields of freshwater fleas (Cladocera) are also abundant. Macrolimnophytes are represented by, for example, Najas minor and Zannichellia palustris. Both can tolerate some brackish water influence, and the sediments contain rare remains of Hydroidea and the ostracode Cythoromorpha fuscata, implying a weak influence of brackish water. The presence of Najas minor seeds indicates that summer temperatures were slightly higher than at present (Bennike et al. 2001). This may be confirmed by the common presence of Cladium mariscus fruits in core 348180, but this plant is calciphilous and its abundance in early Holocene deposits may reflect that leaching of the soils was not as far advanced as today.

In the middle part of the sequence a marked peak in Scirpus spp. (mainly Scirpus tabernaemontani) fruits is seen, and at about the same level Phragmites australis seeds also show a maximum. This may imply erosion of reed beds as the sea level rose.

At around $220 \mathrm{~cm}$ depth Hydrobia ulvae and at around $180 \mathrm{~cm}$ depth Ruppia sp., Potamogeton pectinatus and Littorina littorea appear, indicating increased salinity, followed by Nucula nucleus, Corbula gibba and other marine species that indicate a salinity similar to present values. 


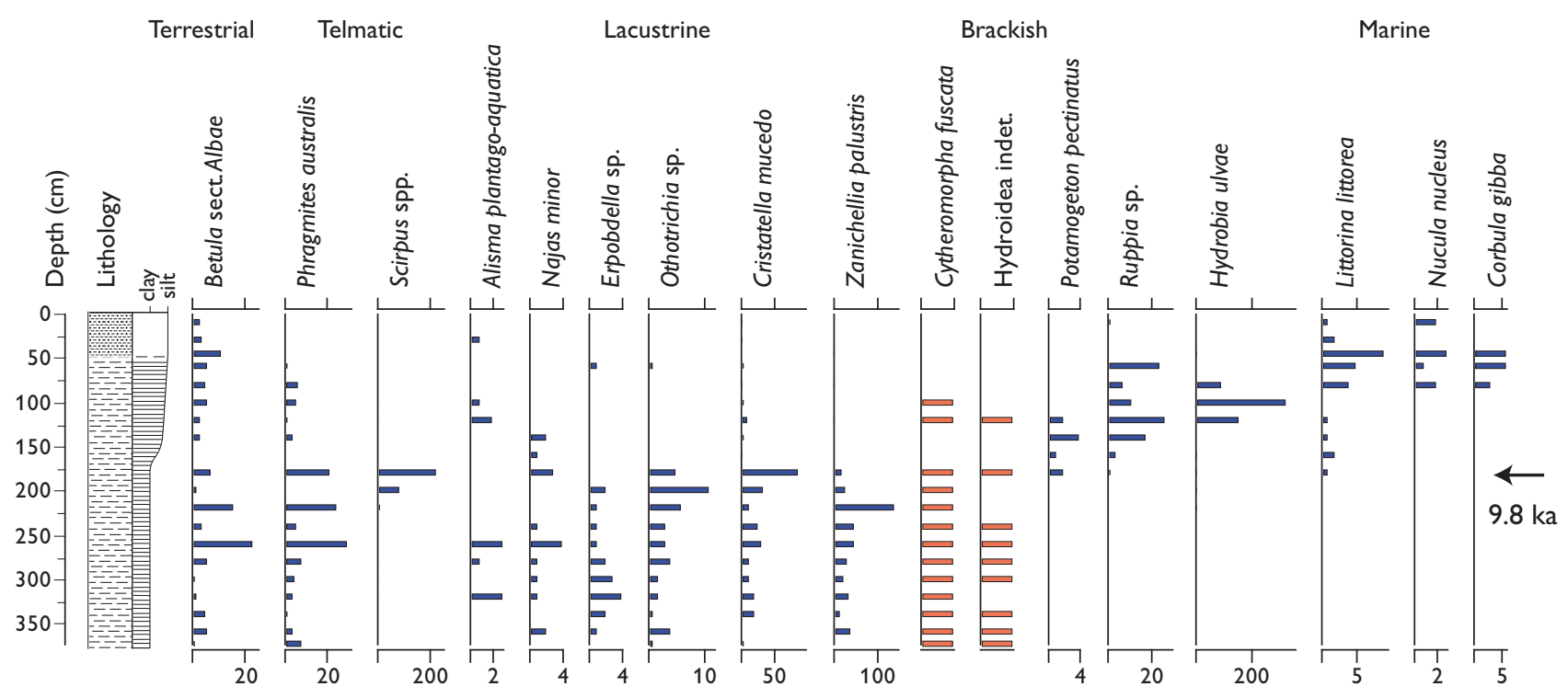

Fig. 3. Strongly simplified macrofossil concentration diagram of core 255150 from Øresund. The core consists of a lower unit of horizontally layered clay and silt and an upper unit of homogenous silty mud. A single sample has been dated to 9686-9887 cal. years BP (Table 1). The red bars show remains that were not counted.

\section{Sea-level changes}

Figure 4 shows a plot of the ages of radiocarbon dated samples against depth. We have included a few samples from archaeological sites (Table 1; Fisher 1993). The full black line shows relative sea-level changes during the mid-Holocene according to Christensen (2001), when a number of small transgressions and regressions occurred. A similar picture may have characterised the late Holocene, but due to lack of data we have drawn a straight, stippled line for this time period.

We have also drawn a straight line for the early Holocene. We consider this unlikely, but the data do not allow us to draw a more elaborate line. The marine and terrestrial samples should fall respectively below and above the line. However, it is not possible to draw the line so that this is fulfilled. This means that some of the ages are not correct. Several explanations for this can be offered. One factor to consider is differential isostatic rebound. The samples come from a fairly large region, but most of the isostatic rebound occurred prior to the Holocene, and the marine limit only falls from $c$. 5.5 to $c .4 \mathrm{~m}$ from north to south (Christensen 2001). Hence we suggest that the depth of the dated samples should be moved by only $1-2 \mathrm{~m}$, which does not change the picture.

We consider two other factors more important. One is the marine reservoir effect, for which a value of 400 years was used, which is common for the region. However, large variations are seen from place to place, and in closed fjords it can be several hundred years greater than the regional value. Variations of several hundred years may also take place over time (Olsen et al. 2009). The other factor is that some mollusc species, such as Macoma balthica used in this study, can take up old carbon from the sediment, and dating of such species may therefore also produce ages that are several hundred years older than contemporaneous terrestrial samples (Mangerud et al. 2006).

Dating of terrestrial samples can also be problematic, and here we have excluded an age determination of a hazel (Corylus avellana) nut fragment that appears to be too young. An explanation for this could be contamination by modern carbon in the laboratory. We consider the other ages

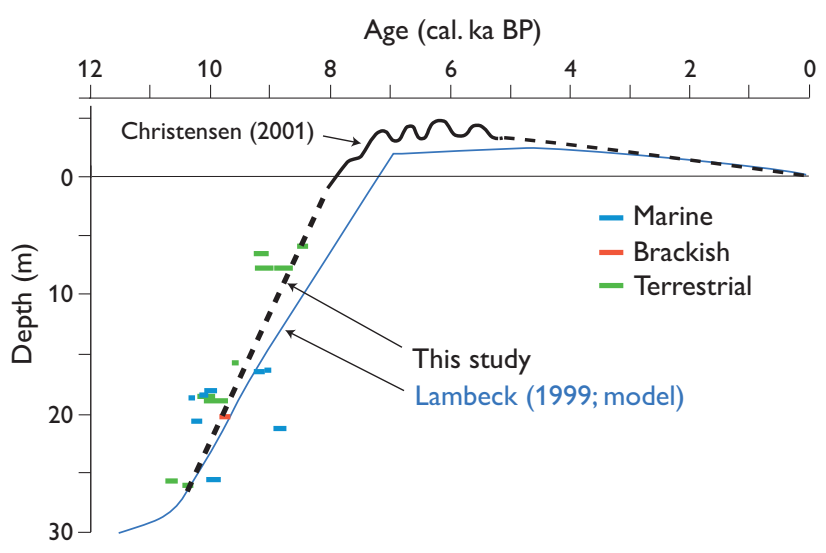

Fig. 4. Tentative curve showing relative sea-level changes in Øresund during the Holocene, based on radiocarbon dated samples. The curve is compared with a curve based on numerical, geophysical modelling by Lambeck (1999). ka: kilo-annum (one thousand years). 
of terrestrial material to be reliable and have drawn the curve so that the terrestrial samples fall above it. According to the curve, the relative sea level rose $c .25 \mathrm{~m}$ to the present level from 10 to $8 \mathrm{ka}$ BP. We have compared the curve with a curve constructed by Lambeck (1999), using numerical modelling, which shows a good fit (Fig. 4).

\section{Discussion and conclusions}

During the earliest Holocene, large parts of Øresund were dry land, but local lakes and bogs existed in depressions. The shore level of the southern Baltic Sea and Kattegat reached a lowstand (Björck 1995). As the water level in Kattegat began to rise, a fjord with brackish water and limited water exchange formed in northern Øresund.

Later, the ongoing eustatic sea-level rise led to increased salinity, and the fjord became larger. At the same time, the water level in the Baltic Basin also increased (Jensen et al. 1999). The threshold in Øresund was flooded between 9 and $8 \mathrm{ka}$, and Øresund developed into a strait.

The oldest dated marine shell from Øresund gave an age of 10.3-10.4 cal. ka BP, but we suggest that this is somewhat too old, and marine water probably did not reach a level of around $25 \mathrm{~m}$ b.s.l. until c. $10 \mathrm{ka}$. However, at the entrance to Øresund where the water depth is $35-40 \mathrm{~m}$, marine waters may have begun to enter several millennia earlier according to Lambeck's model (Fig. 4). In Storebælt, the oldest dated marine shell gave an age of $c .8100$ cal. years BP (Bennike et al. 2004), in the Lillebælt the oldest shell date is $c .7700$ cal. years BP (Bennike \& Jensen 2010) and in Mecklenburger Bucht, the oldest reported shell date is $c .7600$ cal. years BP (Bennike \& Jensen 1998). These differences partly reflect different threshold levels. However, freshwater drainage from the Baltic Basin through Storebælt may also have inhibited marine bivalves from entering this strait for centuries or millennia.

\section{Acknowledgements}

The captain and crew of the former R/V Alexander von Humboldt and $\mathrm{R} / \mathrm{V}$ Professor Penck of the Institut für Ostseeforschung in Warnemünde are thanked for their help during marine cruises.

\section{References}

Andreasen, M.S. 2005: Træk af Øresunds udviklingshistorie gennem tidlig Holocæn, 151 pp. Unpublished cand. scient. thesis, Københavns Universitet, Danmark.

Bennike, O. \& Jensen, J.B. 1998: Late- and postglacial shore level changes in the southwestern Baltic Sea. Bulletin of the Geological Society of Denmark 45, 27-38.

Bennike, O. \& Jensen, J.B. 2010: Postglacial, relative shore-level changes in Lillebælt, Denmark. Geological Survey of Denmark and Greenland Bulletin 23, 37-40.

Bennike, O., Jensen, J.B. \& Lemke, W. 2001: Late Quaternary records of Najas spp. (Najadaceae) from Denmark and surroundings. Review of Palaeobotany and Palynology 114, 259-267.

Bennike, O., Jensen, J.B., Lemke, W., Kuijpers, A. \& Lomholt, S. 2004: Late- and postglacial history of the Great Belt, Denmark. Boreas 33, $18-33$.

Björck, S. 1995: A review of the history of the Baltic Sea, 13.0-8.0 ka BP. Quaternary International 27, 19-40.

Christensen, C. 2001: Kystbosættelse og havniveauændringer i stenalderen. In: Jensen, O.L., Sørensen, S.A. \& Hansen, K.M. (eds): Danmarks jægerstenalder - status og perspektiver, 183-193. Hørsholm: Hørsholm Egns Museum.

Fischer, A. 1993: Stenalderbopladser på bunden af Øresund. Del 1, det centrale Øresund, 103 pp. Copenhagen: Miljø- og Energiministeriet, Skov- og Naturstyrelsen.

Houmark-Nielsen, M. \& Kjær, K.H. 2003: Southwest Scandinavia, 40-15 kyr BP: palaeogeography and environmental change. Journal of Quaternary Science 18, 769-786.

Jensen, J.B., Bennike, O., Witkowski, A., Lemke, W. \& Kuijpers, A. 1999: Early Holocene history of the southwestern Baltic Sea: the Ancylus Lake stage. Boreas 29, 437-453.

Jessen, K. 1923: En undersøisk Mose i Rungsted Havn og de senglaciale Niveauforandringer i Øresund. Danmarks Geologiske Undersøgelse IV. Række 1(18), 18 pp.

Lagerlund, E. \& Houmark-Nielsen, M. 1993: Timing and pattern of the last deglaciation in the Kattegat region, southwest Scandinavia. Boreas 22, 337-347.

Lambeck, K. 1999: Shoreline displacements in southern-central Sweden and the evolution of the Baltic Sea since the last maximum glaciation. Journal of the Geological Society (London) 156, 465-486.

Mangerud, J., Bondevik, S., Gulliksen, S., Hufthammer, A.K. \& Høisæter, T. 2006: Marine ${ }^{14} \mathrm{C}$ reservoir ages for the 19th century whales and molluscs from the North Atlantic. Quaternary Science Reviews 25, $3228-3245$

Olsen, J., Rasmussen, P. \& Heinemeier, J. 2009: Holocene temporal and spatial variation in the radiocarbon reservoir age. Boreas 38, 458-470.

\footnotetext{
Authors' addresses

O.B. \& J.B.J., Geological Survey of Denmark and Greenland, Øster Voldgade 10, DK-1350 Copenhagen K, Denmark. E-mail: obe@geus.dk M.S.A. \& N.N.N., Department of Geography and Geology, University of Copenhagen, Øster Voldgade 10, DK-1350 Copenhagen K, Denmark. M.M., The Leibniz Institute for Baltic Sea Research, Seestrasse 15, Warnemünde, D-18119 Rostock, Germany.
} 